\title{
Separate and Combined Effects of Chlortetracycline and Oxytetracycline on Growth and Antioxidant Enzymes in Myriophyllum Aquaticum
}

Jing Li

Wuhan University

Zhonghua Wu ( $\nabla$ wuzhonghua@whu.edu.cn )

Wuhan University https://orcid.org/0000-0003-0810-7470

\section{Research Article}

Keywords: Chlortetracycline, Oxytetracycline, Myriophyllum aquaticum (Vell.) Verdc, joint effects, antioxidant defense systems

Posted Date: December 15th, 2021

DOI: https://doi.org/10.21203/rs.3.rs-1097797/v1

License: (c) (1) This work is licensed under a Creative Commons Attribution 4.0 International License.

Read Full License 


\section{Abstract}

As two typical tetracyclines, chlortetracycline (CTC) and oxytetracycline (OTC) coexist widely in water. In the experiment, Myriophyllum aquaticum (Vell.) Verdc was exposed to the orthogonal hydroponic environment with the concentrations of CTC and OTC at 1, 10, and $50 \mathrm{mg} / \mathrm{L}$ for 7 days (7 D) and 14 days (14 D). The results showed that the plant height, relative growth rates (RGR), and photosynthetic pigment contents of $M$. aquaticum decreased significantly after $14 \mathrm{D}$ of CTC/ OTC, which was stronger than that after $7 \mathrm{D}$, and the toxicity of CTC was stronger than OTC. The combined toxicity of the two on the RGR and total chlorophyll content was mainly synergistic or additive after $7 \mathrm{D}$. After $14 \mathrm{D}$, the interaction changed to antagonism or addition, and the response of total chlorophyll content was more obvious than that of RGR. After $7 \mathrm{D}$ of combined treatments, the malondialdehyde (MDA) content decreased significantly, superoxide dismutase (SOD), catalase (CAT) and peroxidase (POD) activities responded to different combined concentrations, respectively, and CAT was the main protective enzyme of $M$. aquaticum. After $14 \mathrm{D}$ of combined treatments, the hydrogen peroxide $\left(\mathrm{H}_{2} \mathrm{O}_{2}\right)$ content increased significantly, the MDA content increased first and then decreased, and POD was the main protective enzyme among the three antioxidant enzymes. Overall, this study provided the first insight into the single and combined toxicity of CTC and OTC on the growth and physiology of M. aquaticum at different time periods, revealing the reversal of the combined toxicity with time of exposure.

\section{Introduction}

As natural, semi-synthetic, or synthetic compounds, antibiotics have been widely used to prevent and treat human and animal diseases caused by microbial infections, as well as feed additives to promote the growth of livestock (Kovalakova et al. 2020; Siedlewicz et al. 2020). China has an annual production capacity of about 210,000 tons of antibiotics, 85 percent of which is used in animal husbandry and medicine (Daghrir and Drogui 2013). China, Brazil, India, the United States, and Indonesia are projected to be among the top five countries in the world in the use of antibiotics in livestock by 2030 (Klein et al. 2018). However, antibiotics cannot be fully absorbed or metabolized by organisms, and about $25-75 \%$ of them are released into soil and water as metabolites through urine and feces (Qiu et al. 2020). Due to their high usability, high water solubility, and low bioavailability, antibiotics are detected in high concentrations in aquatic environments around the world (Pan and Chu 2018; Qiu et al. 2019).

Tetracyclines, including chlortetracycline (CTC), oxytetracycline (OTC), tetracycline (TC), and doxycycline (DXC), can inhibit protein synthesis by binding to the $30 \mathrm{~S}$ subunit of microbial ribosomes (Scaria et al. 2021). In the production and use of antibiotics, tetracyclines rank second in the world and first in China (Daghrir and Drogui 2013; Scaria et al. 2021). As two of the ten growth promoters approved in the United States, CTC and OTC are the most commonly used antibiotics in swine production in the United States and aquaculture worldwide, respectively (Wei et al. 2011; Suzuki et al. 2019). Although the half-life of tetracyclines is not long, including about 24 days for CTC and more than 20 days for OTC (Tasho and Cho 2016), they may have a longer half-life than expected under natural conditions, sometimes up to 500 days (Walters et al. 2010; Nieder et al. 2018). CTC and OTC have been widely detected in aquatic 
environments such as surface water, groundwater and seawater. For example, the residual concentrations of CTC and OTC are 130.67 and $82.59 \mathrm{ug} / \mathrm{L}$, respectively, in the wastewater of a pig farm in Tianjin, China (Zhi et al. 2018). The concentrations of OTC as high as $361.1 \mathrm{ug} / \mathrm{L}$ and $56.1 \mathrm{ug} / \mathrm{L}$ were detected in surface water in northern China and Colorado, USA, respectively (Jiang et al. 2014; Kovalakova et al. 2020). In shallow groundwater in northern and southwestern China, the maximum concentrations of CTC and OTC were $8 \mathrm{ng} / \mathrm{L}$ and $237 \mathrm{ng} / \mathrm{L}$, respectively (Chen et al. 2018). In aquaculture ponds near the Yellow Sea in China, the OTC concentration was $7.29 \mathrm{ng} / \mathrm{L}$ and $13.12 \mathrm{ng} / \mathrm{L}$ in wet and dry seasons, respectively (Lu et al. 2019). Studies have found that in the tetracyclines manufacturing industry, the concentrations of OTC and CTC in the water inlet are both high, which are $334.3 \mathrm{mg} / \mathrm{L}$ and $1.8 \mathrm{mg} / \mathrm{L}$, respectively. Even after sewage treatment, about $20 \mathrm{mg} / \mathrm{L}$ of OTC was released into the water body (Hou et al. 2016). More generally, concentrations of CTC and OTC in aquatic environments are recorded in the range $\mathrm{ng} / \mathrm{L}$ to ug/L (Liu et al. 2020).

Tetracyclines exist widely in water and have been proved to have toxic effects on untargeted organisms. In general, tetracyclines are more toxic to microalgae than crustaceans and fish (Daghrir and Drogui 2013). The semi-inhibitory and semi-lethal concentrations of CTC to Microcystis aeruginosa were 0.05 $\mathrm{mg} / \mathrm{L}$ and $15.2 \mathrm{mg} / \mathrm{L}$, respectively (Miazek and Brozek-Pluska 2019). The median inhibitory concentrations of OTC to Ankistrodesmus fusiformis and Chlorella vulgaris were 4.17 and $7 \mathrm{mg} / \mathrm{L}$, respectively (Ando et al. 2007; Carusso et al. 2018). Different kinds of tetracyclines are absorbed and transported differently in plants. The EC50 of CTC and OTC to Medicago sativa were $7.2 \mathrm{ug} / \mathrm{L}$ and 6730 $\mathrm{ug} / \mathrm{L}$, respectively (Scaria et al. 2021). It is worth noting that there is often more than one pollutant in the actual aquatic environment, and the toxic substances in the mixture cause more complex toxicity mechanisms to organisms (Jijie et al. 2021). There are not many studies on the combined toxicity of antibiotics, mainly focusing on the combination of antibiotics and heavy metals (such as $\mathrm{Cu}^{2+}, \mathrm{Zn}^{2+}$ ), the combination between different kinds of antibiotics, and the combined toxicity of antibiotics and other substances (such as phthalate esters and phenolic) (Wei et al. 2018; Qiu et al. 2020; Jijie et al. 2021). In addition, the joint experiments tend to ignore the multi-period studies, and the tested organisms tend to choose algae or fish, while aquatic plants are rarely studied. The combined toxicity of the same antibiotics to aquatic plant over multiple periods of time is not known.

Myriophyllum aquaticum (Vell.) Verdc is a perennial aquatic or emergent plant, widely distributed in tropical and subtropical regions (Liu et al. 2018). It is a promising phytoremediation agent that can absorb nutrients, heavy metals and organic pollutants in water with fast growth and strong environmental adaptability (Liu et al. 2016; Guo et al. 2019). This experiment was conducted to investigate the growth and physiological responses of $M$. aquaticum to individual and combined levels of CTC and OTC at different concentrations (1, 10, $50 \mathrm{mg} / \mathrm{L})$ after 7 days (7 D) and 14 days (14 D). The measurement of plant growth indexes included relative growth rate (RGR) and plant height. The physiological indexes included photosynthetic pigment contents (chlorophyll a, chlorophyll b, total chlorophyll content, and carotenoid), malondialdehyde (MDA), hydrogen peroxide $\left(\mathrm{H}_{2} \mathrm{O}_{2}\right)$, soluble protein contents, and antioxidant enzyme activities, including superoxide dismutase (SOD), catalase (CAT), and 
guaiacol peroxidase (POD). The objectives of this study were: (1) to investigate the single and combined toxicity of CTC and OTC to M. aquaticum, (2) to research the response of antioxidant enzymes of $M$. aquaticum, (3) to discuss the effect of exposure time on the combined toxicity of CTC and OTC.

\section{Methods}

\subsection{Study design}

All the plants used in this experiment were collected from East Lake $\left(30^{\circ} 32^{\prime} \mathrm{N} ; 114^{\circ} 25^{\prime} \mathrm{E}\right)$, Wuhan, China. Each plant was washed with running tap water and rinsed with double steaming water to remove attachments, and then placed in $10 \%$ Hoagland nutrient solution for $7 \mathrm{D}$ of acclimation. After acclimatization, the plant attachments, yellow leaves, and adventitious roots were removed again. Plants of the same size and growth state were selected as experimental material after $15 \mathrm{~cm}$ of the front end of M. aquaticum. CTC and OTC were obtained from chlortetracycline hydrochloride (USP grade, CAS NO. 6472-2) and oxytetracycline hydrochloride (USP grade, 95\% purity, CAS NO. 2058-46-0), all purchased from Wuhan Xinshentest Chemical Technology Co., Ltd., China. CTC and OTC concentrations were set at 1, 10, and $50 \mathrm{mg} / \mathrm{L}$, respectively. A total of 16 treatment groups were included, including 9 different combinations of CTC and OTC, 6 CTC and OTC alone, and 1 control group with only $10 \%$ Hoagland nutrient solution (Table 1). In the experiment, each treatment group was set with 3 replicates, and each replicate contained 4 plants of the same size. The labeled plants were transplanted to $5 \mathrm{~L} 10 \%$ Hoagland nutrient solution with CTC and OTC at treatment concentrations. Change the solution every 48 hours (48 h). The temperature of the experimental greenhouse was controlled at $25 \pm 0.5^{\circ} \mathrm{C}$, the light/dark cycle was $16-\mathrm{h} / 8$-h, the relative air humidity was $60 \%$, and the light intensity was $10,000 \mathrm{~lx}$. After $7 \mathrm{D}$ and $14 \mathrm{D}$, the plants were harvested respectively. After rinsing with double steam water to remove impurities, the surface moisture of the plants was dried, and the indexes were determined.

Table 1

Factorial design during CTC and OTC mixture concentrations

\begin{tabular}{|c|c|c|c|c|}
\hline \multirow[t]{2}{*}{ CTC (mg/L) } & \multicolumn{4}{|c|}{ OTC (mg/L) } \\
\hline & 0 & 1 & 10 & 50 \\
\hline 0 & Control & 1 OTC & 10 OTC & 50 OTC \\
\hline 1 & 1 СТC & $1 \mathrm{CTC}+1$ OTC & 1 СТС+10 ОТС & 1 СТC+50 ОТС \\
\hline 10 & 10 CTC & $10 \mathrm{CTC}+1$ OTC & $10 \mathrm{CTC}+10$ OTC & 10 CTC+50 отC \\
\hline 50 & 50 СТС & 50 CTC+1 OTC & 50 CTC+10 OTC & $50 \mathrm{CTC}+50$ OTC \\
\hline
\end{tabular}

\subsection{Trait measurements}

\subsubsection{Measurement of plant growth}


The plant growth was evaluated by the relative growth rate (RGR) and plant height. The plant height was measured directly with a ruler, and the fresh weight of the plant was measured with an electronic analytical balance (accuracy $0.1 \mathrm{~g}$ ). RGR was calculated according to Liu et al. (Liu et al. 2020).

$R G R=[\ln$ (final weight) $-\ln$ (initial weight) $] / \Delta t\left(\mathrm{~g} \mathrm{~g}^{-1}\right.$ day $\left.^{-1}\right)$, where weight is the plant fresh weight over $\triangle$ t days.

\subsubsection{Photosynthetic pigment measurements}

Photosynthetic pigments include chlorophyll a, chlorophyll b, carotenoid, and total chlorophyll, which are determined according to the method of Jampeetong and Brix (2009). $0.05 \mathrm{~g}$ of fresh plant leaves were evenly cut into pieces and placed in a test tube, $10 \mathrm{~mL}$ of $95 \%(\mathrm{v} / \mathrm{v})$ ethanol was added, and sealed in the dark for $48 \mathrm{~h}$ until the leaves turned white. The absorbance values of the extracts were determined by uv spectrophotometer (MAPADA UV-1200, Shanghai Meipuda Instrument Co. Ltd. China) at 470, 649, and $665 \mathrm{~nm}$, respectively. The method of Lichtenthaler and Wellburn (1983) was used to calculate the photosynthetic pigments.

\subsubsection{Lipid peroxidation measurements}

The degree of lipid peroxidation in plant leaves can be judged by the content of MDA (Cang and Zhao 2013). The determination method of MDA content was as follow: $0.05 \mathrm{~g}$ fresh plant leaves were weighted and evenly cut into pieces, and $3 \mathrm{~mL}$ of $10 \%$ trichloroacetic acid (TCA) was added for grinding. The homogenate after grinding was placed in a centrifuge at $4{ }^{\circ} \mathrm{C}$ and centrifuged at $12,000 \mathrm{~g}$ for $25 \mathrm{~min}$. Take $2 \mathrm{~mL}$ of centrifuged supernatant, add $2 \mathrm{~mL} 0.6 \%$ 2-thiobarbituric acid (TBA), mix evenly and heat in water bath at $100{ }^{\circ} \mathrm{C}$ for $30 \mathrm{~min}$, remove and cool quickly before centrifugation. The absorbance of the supernatant was measured at 450,532, and $600 \mathrm{~nm}$.

\subsection{4 $\mathrm{H}_{2} \mathrm{O}_{2}$ and soluble protein contents measurements}

Refer to Shi (2016) for the determination method of $\mathrm{H}_{2} \mathrm{O}_{2}$ content. Weight and grind $0.1 \mathrm{~g}$ fresh leaves with phosphate buffer solution (50 mM, pH 7.8, containing $1 \%(\mathrm{~m} / \mathrm{v})$ polyvinylpyrrolidone (PVP)) under ice bath, and centrifuge the grinding solution at $4{ }^{\circ} \mathrm{C}$ for $12,000 \mathrm{~g}$ for $25 \mathrm{~min}$ (Eppendorf Centrifuge 5417 R, Hamburg, Germany). After centrifugation, $1.5 \mathrm{~mL}$ sample extract was added to $1.5 \mathrm{~mL} 5 \%(\mathrm{~W} / \mathrm{V})$ titanium sulfate, placed for $10 \mathrm{~min}$, and centrifuged again at $4{ }^{\circ} \mathrm{C}$ for $12,000 \mathrm{~g}$ for $15 \mathrm{~min}$. The absorbance of supernatant was measured at $410 \mathrm{~nm}$.

The soluble protein content of plants was determined by Coomassie bright blue G-250 staining (Bradford 1976).

\subsubsection{Enzyme activities measurements}

Weight $0.1 \mathrm{~g}$ fresh plant leaves, add phosphate buffer solution (50 mM, pH 7.8) and grind them in an ice bath, centrifuge them at $12,000 \mathrm{~g}$ for $25 \mathrm{~min}$ in a frozen centrifuge. The supernatant after centrifugation was used for determination of antioxidant enzymes. 
The activity of SOD was determined by NBT photochemical reduction (Cang and Zhao 2013). The reaction mixture consisted of $1.5 \mathrm{~mL}$ phosphate buffer solution ( $50 \mathrm{mM}, \mathrm{pH} 7.8), 0.3 \mathrm{~mL}$ methionine solution (130 mM), $0.3 \mathrm{~mL}$ EDTA-Na ${ }_{2}$ solution ( $\left.3 \mathrm{uM}\right), 0.3 \mathrm{~mL}$ riboflavin $(20 \mathrm{uM}), 0.1 \mathrm{~mL}$ crude enzyme solution and $0.5 \mathrm{~mL}$ distilled water. The SOD activity unit (U/g FW) was defined as an enzyme activity unit that inhibited $50 \%$ of NBT photochemical reduction. The activity of CAT was measured at $240 \mathrm{~nm}$ by uv absorption method (Cang and Zhao 2013). The reaction mixture consisted of $1.5 \mathrm{~mL}$ PBS $(0.2 \mathrm{M} \mathrm{pH}$ 7.8), $0.3 \mathrm{~mL} \mathrm{H} \mathrm{H}_{2} \mathrm{O}_{2}$ solution $(0.1 \mathrm{M}), 0.2 \mathrm{~mL}$ crude enzyme solution, and $1 \mathrm{~mL}$ distilled water. The activity of POD was determined by guaiacol method at $470 \mathrm{~nm}$ (Liu and Li 2007). The reaction mixture consisted of $2.9 \mathrm{~mL}$ PBS (0.1 M, pH 6.0), $1.0 \mathrm{~mL}$ guaiacol $(0.05 \mathrm{mM}), 1.0 \mathrm{mLH}_{2} \mathrm{O}_{2}(2 \%)$ and $0.1 \mathrm{~mL}$ crude enzyme solution.

\subsubsection{Joint toxicity assessment method}

The Abott model was used to evaluate the combined toxicity of CTC and OTC to M. aquaticum after $7 \mathrm{D}$ and $14 \mathrm{D}$. In this model, the observed inhibition of CTC and OTC combined pollution is represented by $\mathrm{C}_{\mathrm{obs}}(\%)$, and the predicted inhibition of combined pollution is represented by $\mathrm{C}_{\exp }(\%)$. The calculation method of $\mathrm{C}_{\exp }(\%)$ is as follow:

$C_{\text {exp }}=A+B-\left(\frac{A B}{100}\right)$

Where, A and B represent the inhibition levels of CTC or OTC alone on $M$. aquaticum.

The Abott model evaluated the effect of combined toxicity by comparing RI with 1 . The calculation method of RI is as follow:

$\mathrm{RI}=\mathrm{C}_{\text {obs }} / \mathrm{C}_{\exp }$

$\mathrm{RI}>1$ indicates that the interaction between CTC and OTC is synergistic, $\mathrm{RI}=1$ indicates simple addition, and $\mathrm{RI}<1$ indicates antagonism between CTC and OTC. The interactions of CTC and OTC are considered to be significantly different from addition only when RI values are significantly different from 1 (Chesworth et al. 2004; Gatidou and Thomaidis 2007).

\subsection{Date analysis}

Statistical analysis was performed using SPSS 23.0 for Windows (IBM Inc., Chicago, IL, USA). Homogeneity of variance was analyzed by Levene's test. When necessary, the date was transformed and normalized to reduce variance heterogeneity., and then significance analysis was performed for control and treatment groups using one-way ANOVA. P-values $\leq 0.05$ were considered significant. The experimental data were expressed as mean \pm standard deviation. graphs using SigmaPlot 12.5 for Windows (Systat Software, Inc., USA).

\section{Results}




\subsection{Plant growth}

After $7 \mathrm{D}$, there was no significant difference in the plant height of $M$. aquaticum between all treatment groups and control group ( $p>0.05$ ) (Fig. 1a). No matter under single CTC/ OTC or combined treatments, the plant height of $M$. aquaticum decreased significantly after $14 \mathrm{D}$. Under single treatments, $1 \mathrm{mg} / \mathrm{L}$ CTC/ OTC could significantly reduce the plant height of $M$. aquaticum by $91.78 \%$ and $91.20 \%$ of the control, respectively $(p<0.05)$. Under the combined treatment of low concentration $(1+1 \mathrm{mg} / \mathrm{L})$, the plant height was significantly lower than that of the control, which was $89.51 \%(p<0.05)$. Under the combined treatment of high concentration $(50+50 \mathrm{mg} / \mathrm{L})$, the plant height reached the minimum value, which was $76.27 \%$ of the control (Fig. 1b).

After $7 \mathrm{D}$, the RGR of $M$. aquaticum significantly increased at $1 \mathrm{mg} / \mathrm{L} \mathrm{CTC}$, which was $27.27 \%$ higher than that of the control $(p<0.05)$, and then returned to the control level. However, there was no significant difference in the RGR of $M$. aquaticum compared with the control under OTC treatments $(p>0.05)$. After $7 \mathrm{D}$ of CTC and OTC combined treatments, OTC supplementation reduced the RGR of $M$. aquaticum under all CTC concentrations, and the lowest RGR appeared in the $(50+10 \mathrm{mg} / \mathrm{L})$ treatment of CTC and OTC, which decreased by $68 \%$ compared with the control. At the highest concentration of CTC and OTC combined treatment $(50+50 \mathrm{mg} / \mathrm{L})$, the RGR slightly increased, but still significantly lower than the control group (Fig. 2a). After 14 D, the RGR of M. aquaticum showed obvious concentration dependence, that is, the RGR decreased with the increase of treatment concentrations. The minimum values were reached at $50 \mathrm{mg} / \mathrm{L} \mathrm{CTC}, 50 \mathrm{mg} / \mathrm{L}$ OTC, and (50+50) mg/L combined treatments of CTC and OTC, which decreased by $36.44 \%, 27.77 \%$, and $63.44 \%$ compared with the control, respectively (Fig. $2 b$ ).

\subsection{Photosynthetic pigments}

After $7 \mathrm{D}$, the contents of chlorophyll a and chlorophyll b at $10 \mathrm{mg} / \mathrm{L} \mathrm{CTC}$ were significantly lower than those in control group $(p<0.05)$. The contents of total chlorophyll and carotenoid had no significant changes under CTC treatments $(p>0.05)$. There was no significant difference in the photosynthetic pigment contents after $7 \mathrm{D}$ of exposure to OTC $(p>0.05)$. Under $(1+10) \mathrm{mg} / \mathrm{L}$ combined treatment of CTC and OTC, the contents of chlorophyll a, chlorophyll b, and total chlorophyll reached the lowest point, which decreased by $29.41 \%, 28.57 \%$, and $29.21 \%$, respectively, compare with the control $(p<0.05)$. All treatment groups had no significant effect on the carotenoid content of $M$. aquaticum $(p>0.05)$ (Table 2). 
Effect of CTC, OTC, and their mixture on chlorophyll a, chlorophyll b, total chlorophyll content, and carotenoid of M. aquaticum after $7 \mathrm{D}$

\begin{tabular}{|c|c|c|c|c|c|}
\hline $\begin{array}{l}\text { CTC } \\
\text { concentration } \\
\text { (mg/L) }\end{array}$ & $\begin{array}{l}\text { OTC } \\
\text { concentration } \\
(\mathrm{mg} / \mathrm{L})\end{array}$ & $\begin{array}{l}\text { Chlorophyll a } \\
\text { content } \\
\text { (mg/g FW) }\end{array}$ & $\begin{array}{l}\text { Chlorophyll } \\
\text { b content } \\
\text { (mg/g FW) }\end{array}$ & $\begin{array}{l}\text { Total } \\
\text { chlorophyll } \\
\text { content } \\
(\mathrm{mg} / \mathrm{g} \mathrm{FW})\end{array}$ & $\begin{array}{l}\text { Carotenoid } \\
\text { content } \\
\text { (mg/g FW) }\end{array}$ \\
\hline 0 & 0 & $0.68 \pm 0.01 a b$ & $0.21 \pm 0.01 a b$ & $0.89 \pm 0.01 \mathrm{abcd}$ & $0.19 \pm 0.02 b c$ \\
\hline 0 & 1 & $0.68 \pm 0.05 a b$ & $0.21 \pm 0.01 \mathrm{ab}$ & $0.89 \pm 0.06 a b c$ & $0.19 \pm 0.02 b c$ \\
\hline 0 & 10 & $0.66 \pm 0.10 \mathrm{abc}$ & $0.23 \pm 0.02 a$ & $0.92 \pm 0.06 \mathrm{ab}$ & $0.19 \pm 0.01 b c$ \\
\hline 0 & 50 & $0.69 \pm 0.08 a$ & $0.22 \pm 0.03 a b$ & $0.91 \pm 0.11 a b c$ & $0.21 \pm 0.01 a b$ \\
\hline 1 & 0 & $0.61 \pm 0.09 \mathrm{abcd}$ & $0.19 \pm 0.02 b c$ & $0.79 \pm 0.12 \mathrm{bcde}$ & $0.19 \pm 0.01 \mathrm{c}$ \\
\hline 1 & 1 & $0.55 \pm 0.02 \mathrm{bcd}$ & $0.19 \pm 0.02 b c$ & $0.78 \pm 0.11 \mathrm{bcde}$ & $0.20 \pm 0.01 \mathrm{abc}$ \\
\hline 1 & 10 & $0.48 \pm 0.08 d$ & $0.15 \pm 0.02 d$ & $0.63 \pm 0.10 \mathrm{e}$ & $0.20 \pm 0.01 \mathrm{abc}$ \\
\hline 1 & 50 & $0.53 \pm 0.02 \mathrm{~cd}$ & $0.19 \pm 0.02 b c$ & $0.79 \pm 0.09 \mathrm{bcde}$ & $0.20 \pm 0.01 \mathrm{abc}$ \\
\hline 10 & 0 & $0.50 \pm 0.07 d$ & $0.16 \pm 0.02 \mathrm{~cd}$ & $0.72 \pm 0.17 \mathrm{de}$ & $0.20 \pm 0.01 a b c$ \\
\hline 10 & 1 & $0.54 \pm 0.08 \mathrm{~cd}$ & $0.15 \pm 0.01 d$ & $0.70 \pm 0.11 \mathrm{e}$ & $0.20 \pm 0.02 a b c$ \\
\hline 10 & 10 & $0.56 \pm 0.11 \mathrm{bcd}$ & $0.16 \pm 0.03 c d$ & $0.66 \pm 0.18 \mathrm{e}$ & $0.19 \pm 0.01 a b c$ \\
\hline 10 & 50 & $0.68 \pm 0.03 a b$ & $0.22 \pm 0.02 a b$ & $0.90 \pm 0.05 a b c$ & $0.21 \pm 0.01 \mathrm{abc}$ \\
\hline 50 & 0 & $0.58 \pm 0.07 a b c d$ & $0.18 \pm 0.02 b c$ & $0.76 \pm 0.09 \mathrm{cde}$ & $0.20 \pm 0.02 a b c$ \\
\hline 50 & 1 & $0.67 \pm 0.12 a b$ & $0.23 \pm 0.01 a$ & $0.97 \pm 0.06 a$ & $0.21 \pm 0.01 \mathrm{ab}$ \\
\hline 50 & 10 & $0.59 \pm 0.06 \mathrm{abcd}$ & $0.18 \pm 0.02 b c$ & $0.78 \pm 0.09 \mathrm{bcde}$ & $0.19 \pm 0.01 \mathrm{abc}$ \\
\hline 50 & 50 & $0.59 \pm 0.05 \mathrm{abcd}$ & $0.19 \pm 0.01 b c$ & $0.78 \pm 0.07 \mathrm{bcde}$ & $0.21 \pm 0.01 \mathrm{abc}$ \\
\hline
\end{tabular}

After $14 \mathrm{D}$, chlorophyll a, chlorophyll $\mathrm{b}$, and total chlorophyll contents of $M$. aquaticum showed the same trend, which showed obvious concentration dependence, that is, decreased with the increase of CTC and OTC concentrations. The three indexes of $M$. aquaticum significantly decreased to the minimum value at $50 \mathrm{mg} / \mathrm{L} \mathrm{CTC}$, which were $33.78 \%, 37.5 \%$, and $35.35 \%$ lower than those of the control. respectively ( $\mathrm{p}<$ 0.05). They reached the minimum value at $10 \mathrm{mg} / \mathrm{L}$ OTC, which were $22.97 \%, 25 \%$, and $25.25 \%$ lower than the control group, respectively $(p<0.05)$. Under $(10+50) \mathrm{mg} / \mathrm{L}$ of CTC and OTC combined treatment, they reached the minimum value, which were $58.11 \%, 57.11 \%$, and $54.55 \%$ of the control group, 
respectively $(p<0.05)$. The carotenoid content of $M$. aquaticum increased significantly only under $(50+50) \mathrm{mg} / \mathrm{L}$ combined treatment $(\mathrm{p}<0.05)($ Table 3$)$.

Table 3

Effect of CTC, OTC, and their mixture on chlorophyll a, chlorophyll b, total chlorophyll content, and carotenoid of M. aquaticum after $14 \mathrm{D}$

\begin{tabular}{|c|c|c|c|c|c|}
\hline $\begin{array}{l}\text { CTC } \\
\text { concentration } \\
\text { (mg/L) }\end{array}$ & $\begin{array}{l}\text { OTC } \\
\text { concentration } \\
(\mathrm{mg} / \mathrm{L})\end{array}$ & $\begin{array}{l}\text { Chlorophyll } \\
\text { a content } \\
\text { (mg/g FW) }\end{array}$ & $\begin{array}{l}\text { Chlorophyll b } \\
\text { content } \\
\text { (mg/g FW) }\end{array}$ & $\begin{array}{l}\text { Total chlorophyll } \\
\text { content }(\mathrm{mg} / \mathrm{g} \\
\text { FW) }\end{array}$ & $\begin{array}{l}\text { Carotenoid } \\
\text { content } \\
\text { (mg/g FW) }\end{array}$ \\
\hline 0 & 0 & $0.74 \pm 0.02 a$ & $0.24 \pm 0.01 a$ & $0.99 \pm 0.05 a$ & $0.18 \pm 0.01 b$ \\
\hline 0 & 1 & $0.60 \pm 0.02 b$ & $0.18 \pm 0.01 a b c$ & $0.78 \pm 0.04 b$ & $0.18 \pm 0.01 a b$ \\
\hline 0 & 10 & $0.57 \pm 0.01 b c$ & $0.17 \pm 0.01 b c$ & $0.74 \pm 0.02 b c$ & $0.18 \pm 0.01 a b$ \\
\hline 0 & 50 & $0.58 \pm 0.06 b$ & $0.18 \pm 0.02 a b c$ & $0.76 \pm 0.09 b$ & $0.18 \pm 0.02 a b$ \\
\hline 1 & 0 & $0.63 \pm 0.04 b$ & $0.19 \pm 0.01 \mathrm{ab}$ & $0.82 \pm 0.05 b$ & $0.18 \pm 0.01 a b$ \\
\hline 1 & 1 & $0.59 \pm 0.07 \mathrm{~b}$ & $0.18 \pm 0.02 a b c$ & $0.81 \pm 0.06 \mathrm{bc}$ & $0.19 \pm 0.00 \mathrm{ab}$ \\
\hline 1 & 10 & $0.55 \pm 0.09 b c$ & $0.19 \pm 0.03 a b c$ & $0.76 \pm 0.10 \mathrm{~b}$ & $0.18 \pm 0.01 a b$ \\
\hline 1 & 50 & $0.58 \pm 0.04 b$ & $0.18 \pm 0.01 b c$ & $0.76 \pm 0.05 b$ & $0.18 \pm 0.01 a b$ \\
\hline 10 & 0 & $0.62 \pm 0.06 \mathrm{~b}$ & $0.18 \pm 0.02 a b c$ & $0.80 \pm 0.08 b$ & $0.18 \pm 0.01 a b$ \\
\hline 10 & 1 & $0.60 \pm 0.05 b$ & $0.17 \pm 0.02 b c$ & $0.77 \pm 0.07 \mathrm{~b}$ & $0.18 \pm 0.01 a b$ \\
\hline 10 & 10 & $0.62 \pm 0.03 \mathrm{~b}$ & $0.18 \pm 0.01 b c$ & $0.79 \pm 0.04 b$ & $0.18 \pm 0.01 a b$ \\
\hline 10 & 50 & $0.43 \pm 0.07 d$ & $0.12 \pm 0.01 \mathrm{c}$ & $0.54 \pm 0.10 \mathrm{e}$ & $0.18 \pm 0.02 \mathrm{ab}$ \\
\hline 50 & 0 & $0.49 \pm 0.03 \mathrm{~cd}$ & $0.15 \pm 0.01 b c$ & $0.64 \pm 0.04 \mathrm{de}$ & $0.19 \pm 0.02 \mathrm{ab}$ \\
\hline 50 & 1 & $0.49 \pm 0.03 \mathrm{~cd}$ & $0.14 \pm 0.01 \mathrm{c}$ & $0.63 \pm 0.03 \mathrm{de}$ & $0.18 \pm 0.01 a b$ \\
\hline 50 & 10 & $0.50 \pm 0.05 \mathrm{~cd}$ & $0.15 \pm 0.02 b c$ & $0.65 \pm 0.07 \mathrm{~cd}$ & $0.19 \pm 0.01 a b$ \\
\hline 50 & 50 & $0.44 \pm 0.03 d$ & $0.13 \pm 0.01 \mathrm{c}$ & $0.60 \pm 0.07 \mathrm{de}$ & $0.20 \pm 0.01 a$ \\
\hline
\end{tabular}

3.3 MDA content

After 7 D, OTC stress had no significant effect on the MDA content of $M$. aquaticum $(p>0.05)$. At 50 $\mathrm{mg} / \mathrm{L} \mathrm{CTC}$, the content of MDA significantly decreased by $42.07 \%$ compared with the control $(p<0.05)$.

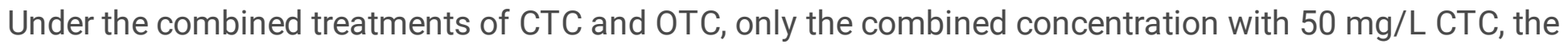
MDA content decreased significantly $(p<0.05)$, and reached the minimum value under the $(50+10)$ $\mathrm{mg} / \mathrm{L}$ treatment (decreased by $42.28 \%$ compared with the control) (Fig. 3a). 
After $14 \mathrm{D}$, there was no significant difference in the MDA content when $M$. aquaticum plants were exposed to CTC/ OTC $(p>0.05)$. The MDA content of $M$. aquaticum increased first and then decreased with the increase of CTC and OTC combined concentrations. Under the treatment of $(1+50) \mathrm{mg} / \mathrm{L}$ of CTC and OTC, the MDA content significantly increased to the maximum, which was 1.89 times of that of the control $(p<0.05)$. At $(50+50) \mathrm{mg} / \mathrm{L}$, the MDA content decreased to the lowest value, which decreased by $76.88 \%$ compared with the control $(p<0.05)$ (Fig. 3b).

3.4 $\mathrm{H}_{2} \mathrm{O}_{2}$ and soluble protein contents

After $7 \mathrm{D}$, all treatment groups had no significant effects on the $\mathrm{H}_{2} \mathrm{O}_{2}$ content of M. aquaticum $(p>0.05)$

(Fig. 4a). After 14 D, both CTC and OTC treatments showed no significant difference in the $\mathrm{H}_{2} \mathrm{O}_{2}$ content, but it was significantly higher than that of control group at medium and high combined concentrations $((10+10) \mathrm{mg} / \mathrm{L},(10+50) \mathrm{mg} / \mathrm{L},(50+1) \mathrm{mg} / \mathrm{L},(50+10) \mathrm{mg} / \mathrm{L}$, and $(50+50) \mathrm{mg} / \mathrm{L})$. The content of $\mathrm{H}_{2} \mathrm{O}_{2}$ in $(50+50) \mathrm{mg} / \mathrm{L}$ of CTC and OTC mixture was $39.59 \mathrm{umol} / \mathrm{g} \mathrm{FW}$, which was 1.32 times of that in the control group (Fig. 4b).

After $7 \mathrm{D}$ and $14 \mathrm{D}$, the soluble protein content of $M$. aquaticum was no significantly affected by all concentration treatment groups $(p>0.05)$ (Fig. $5 a$ and $b$ ).

3.5 Enzyme activities

After $7 \mathrm{D}$, the activities of SOD, CAT, and POD increased first and then decreased at single CTC exposure. The SOD activity reached the maximum value at $1 \mathrm{mg} / \mathrm{L} \mathrm{CTC}$, while the CAT and POD activities reached the maximum value at $10 \mathrm{mg} / \mathrm{L} \mathrm{CTC}$, which were 1.18, 1.44, and 1.27 times of that of the control, respectively. The activities of SOD and CAT did not change significantly under single OTC treatments $(p>$ $0.05)$. The POD activity decreased significantly by $27 \%$ compared with the control at $50 \mathrm{mg} / \mathrm{L} \mathrm{OTC}(p<$ 0.05). The activities of the three enzymes also increased first and then decreased significantly under the combined treatments of CTC and OTC. The activities of three enzymes reached the maximum values under the combined treatments $(1+1) \mathrm{mg} / \mathrm{L},(10+50) \mathrm{mg} / \mathrm{L}$, and $(50+1) \mathrm{mg} / \mathrm{L}$ of CTC and OTC, respectively, which were 1.13 times, 1.69 times and 1.58 times of that of the control. Under the combined treatment of $(50+50) \mathrm{mg} / \mathrm{L} \mathrm{CTC}$ and OTC, the activities of SOD and POD were only $33.08 \%$ and $65.11 \%$ of the control group, while the CAT activity returned to the control group level (Fig. 6a, c and e).

After $14 \mathrm{D}$, the activities of CAT and POD did not change significantly, and the SOD activity reached the lowest value at $50 \mathrm{mg} / \mathrm{L} \mathrm{CTC/} \mathrm{OTC}$, which decreased by $47.94 \%$ and $44.43 \%$ compared with the control, respectively. Under combined treatments, OTC did not significantly change the SOD activity of $M$. aquaticum at low concentration of CTC $(1 \mathrm{mg} / \mathrm{L})(p>0.05)$. With the increase of CTC concentrations, OTC significantly reduced the SOD activity, which was lower than that of CTC alone. At the high concentration of CTC and OTC $(50+50) \mathrm{mg} / \mathrm{L}$, the SOD activity reached the lowest value (only $15.68 \%$ of the control). There was no significant change in the CAT activity of $M$. aquaticum $(p>0.05)$. After $14 \mathrm{D}$ of CTC and OTC combined treatments, the POD activity changed similar to that of $7 \mathrm{D}$. With the increase of the combined treatments, the POD activity first increased and then decreased. It reached the maximum value at the combined treatment of $(1+50) \mathrm{mg} / \mathrm{L}$, increased by $89.05 \%$ compared with the control group 
$(p<0.05)$, and recovered to the level of the control group at $(50+50) \mathrm{mg} / \mathrm{L}$ combined concentration of CTC and OTC (Fig. 6b, d and f).

\subsection{Combined toxicity assessment}

In this study, the RGR and total chlorophyll content were used as indicators to evaluate the combined toxicity of CTC and OTC to $M$. aquaticum after $7 \mathrm{D}$ and $14 \mathrm{D}$. The results showed that the interaction between CTC and OTC was different at treatment time and the combined concentrations of CTC and OTC.

For the RGR, RI value was close to or significantly greater than 1 at each combined concentration of CTC and OTC after $7 \mathrm{D}$, showing additive or synergistic effect. After $14 \mathrm{D}, \mathrm{RI}$ value of OTC mixed with high concentration of CTC (50 mg/L) was significantly less than 1, indicating that CTC and OTC had antagonistic effect on the leaves of $M$. aquaticum (Table 4). 
Table 4

Abott modeling for the binary mixture of CTC and OTC after $7 \mathrm{D}$ and $14 \mathrm{D}$

\begin{tabular}{|c|c|c|c|c|c|c|c|}
\hline Indicators & Time & $\begin{array}{l}\text { CTC } \\
\text { (mg/L) }\end{array}$ & $\begin{array}{l}\text { OTC } \\
\text { (mg/L) }\end{array}$ & $\begin{array}{l}\text { Observed } \\
\text { Inhibition } \\
\left(\mathrm{C}_{\text {obs }}\right)(\%)\end{array}$ & $\begin{array}{l}\text { Excepted } \\
\text { Inhibition } \\
\left(\mathrm{C}_{\text {exp }}\right)(\%)\end{array}$ & RI & $\begin{array}{l}\text { Type of } \\
\text { interaction }\end{array}$ \\
\hline \multirow[t]{18}{*}{ RGR } & \multirow[t]{9}{*}{$7 D$} & \multirow[t]{3}{*}{1} & 1 & $-3.23 \pm 1.68$ & -2.85 & $1.13 \pm 0.59$ & additivity \\
\hline & & & 10 & $14.29 \pm 4.81$ & 3.22 & $4.43 \pm 1.49 *$ & synergism \\
\hline & & & 50 & $35.12 \pm 4.31$ & 5.65 & $6.21 \pm 1.65^{\star}$ & synergism \\
\hline & & \multirow[t]{3}{*}{10} & 1 & $28.74 \pm 2.34$ & 34.91 & $0.82 \pm 0.30$ & additivity \\
\hline & & & 10 & $52.83 \pm 2.22$ & 38.75 & $1.36 \pm 0.24$ & additivity \\
\hline & & & 50 & $56.24 \pm 1.90$ & 40.29 & $1.40 \pm 0.30$ & additivity \\
\hline & & \multirow[t]{3}{*}{50} & 1 & $38.01 \pm 1.99$ & 41.62 & $0.91 \pm 0.43$ & additivity \\
\hline & & & 10 & $54.90 \pm 2.19$ & 45.07 & $1.22 \pm 0.00 *$ & synergism \\
\hline & & & 50 & $58.16 \pm 1.25$ & 46.45 & $1.25 \pm 0.18$ & additivity \\
\hline & \multirow[t]{9}{*}{$14 \mathrm{D}$} & \multirow[t]{3}{*}{1} & 1 & $19.13 \pm 1.00$ & 25.88 & $0.74 \pm 0.31$ & additivity \\
\hline & & & 10 & $32.97 \pm 1.76$ & 40.95 & $0.81 \pm 0.43$ & additivity \\
\hline & & & 50 & $20.49 \pm 1.06$ & 33.82 & $0.61 \pm 0.30$ & additivity \\
\hline & & \multirow[t]{3}{*}{10} & 1 & $72.04 \pm 2.28$ & 76.98 & $0.94 \pm 0.42$ & additivity \\
\hline & & & 10 & $78.67 \pm 1.56$ & 81.66 & $0.96 \pm 0.08$ & additivity \\
\hline & & & 50 & $83.47 \pm 0.09$ & 79.44 & $1.05 \pm 0.00$ & additivity \\
\hline & & \multirow[t]{3}{*}{50} & 1 & $58.27 \pm 1.62$ & 67.41 & $0.63 \pm 0.15^{\star}$ & antagonism \\
\hline & & & 10 & $60.57 \pm 1.69$ & 74.03 & $0.65 \pm 0.12^{*}$ & antagonism \\
\hline & & & 50 & $74.95 \pm 0.71$ & 70.90 & $0.88 \pm 0.01 *$ & antagonism \\
\hline
\end{tabular}

Expected inhibition $\left(\mathrm{C}_{\mathrm{exp}}\right)$ and ratio of inhibition $(\mathrm{RI})$ were calculated according to Abott's formula.

* Represent significant differences ( $p<0.05$, Duncan test).

For total chlorophyll content, after $7 \mathrm{D}$, RI value was significantly lower than 1 only when the combined concentration of CTC and OTC was $(10+50) \mathrm{mg} / \mathrm{L}$ and $(50+1) \mathrm{mg} / \mathrm{L}$, indicating that CTC and OTC showed antagonistic effect. In other combined treatments of CTC and OTC, RI value was close to or significantly great than 1 , and CTC and OTC showed additive or synergistic effect. After $14 \mathrm{D}, \mathrm{RI}$ values were close to or less than 1 , and all showed antagonism except $(10+50) \mathrm{mg} / \mathrm{L}$ combined treatment (Table $5)$. 
Table 5

Abott modeling for the binary mixture of CTC and OTC after $7 \mathrm{D}$ and $14 \mathrm{D}$

\begin{tabular}{|c|c|c|c|c|c|c|c|}
\hline Indicators & Time & $\begin{array}{l}\text { CTC } \\
\text { (mg/L) }\end{array}$ & $\begin{array}{l}\text { OTC } \\
(\mathrm{mg} / \mathrm{L})\end{array}$ & $\begin{array}{l}\text { Observed } \\
\text { Inhibition } \\
\left(\mathrm{C}_{\text {obs }}\right)(\%)\end{array}$ & $\begin{array}{l}\text { Excepted } \\
\text { Inhibition } \\
\left(\mathrm{C}_{\text {exp }}\right)(\%)\end{array}$ & $\mathrm{RI}$ & $\begin{array}{l}\text { Type of } \\
\text { interaction }\end{array}$ \\
\hline \multirow{18}{*}{$\begin{array}{l}\text { Total } \\
\text { chlorophyll } \\
\text { content }\end{array}$} & \multirow[t]{9}{*}{$7 D$} & \multirow[t]{3}{*}{1} & 1 & $18.05 \pm 2.84$ & 10.19 & $1.77 \pm 0.28 *$ & synergism \\
\hline & & & 10 & $29.79 \pm 1.08$ & 18.72 & $1.59 \pm 0.06^{*}$ & synergism \\
\hline & & & 50 & $18.42 \pm 5.79$ & 13.59 & $1.36 \pm 0.43$ & additivity \\
\hline & & \multirow[t]{3}{*}{10} & 1 & $21.05 \pm 1.13$ & 6.83 & $3.00 \pm 0.17^{*}$ & synergism \\
\hline & & & 10 & $24.81 \pm 1.30$ & 15.67 & $1.52 \pm 0.12^{\star}$ & synergism \\
\hline & & & 50 & $-4.04 \pm 1.93$ & 10.35 & $-0.39 \pm 0.19 *$ & antagonism \\
\hline & & \multirow[t]{3}{*}{50} & 1 & $-7.89 \pm 1.72$ & 7.92 & $-1.00 \pm 0.22^{*}$ & antagonism \\
\hline & & & 10 & $21.00 \pm 0.35$ & 16.66 & $1.26 \pm 0.02^{\star}$ & synergism \\
\hline & & & 50 & $12.03 \pm 1.30$ & 11.40 & $1.06 \pm 0.11$ & additivity \\
\hline & \multirow[t]{9}{*}{$14 \mathrm{D}$} & \multirow[t]{3}{*}{1} & 1 & $19.60 \pm 1.67$ & 35.44 & $0.55 \pm 0.02 *$ & antagonism \\
\hline & & & 10 & $23.68 \pm 2.66$ & 38.55 & $0.61 \pm 0.25^{\star}$ & antagonism \\
\hline & & & 50 & $25.38 \pm 1.19$ & 42.84 & $0.59 \pm 0.10$ * & antagonism \\
\hline & & \multirow[t]{3}{*}{10} & 1 & $22.54 \pm 1.84$ & 37.07 & $0.61 \pm 0.18$ * & antagonism \\
\hline & & & 10 & $20.43 \pm 0.87$ & 40.10 & $0.51 \pm 0.10^{*}$ & antagonism \\
\hline & & & 50 & $45.25 \pm 1.98$ & 44.29 & $1.02 \pm 0.23$ & additivity \\
\hline & & \multirow[t]{3}{*}{50} & 1 & $36.26 \pm 0.32$ & 49.79 & $0.73 \pm 0.08 *$ & antagonism \\
\hline & & & 10 & $34.40 \pm 2.29$ & 52.21 & $0.66 \pm 0.14 *$ & antagonism \\
\hline & & & 50 & $38.39 \pm 1.90$ & 55.55 & $0.69 \pm 0.12^{*}$ & antagonism \\
\hline
\end{tabular}

Expected inhibition ( $\left.\mathrm{C}_{\text {exp }}\right)$ and ratio of inhibition (RI) were calculated according to Abott's formula.

* Represent significant differences ( $p<0.05$, Duncan test).

\section{Discussion}

The aerenchyma structure of $M$. aquaticum with stem and root connecting is of great ability to absorb nutrients in water. No matter under single CTC/ OTC or combined treatments, the plant height and RGR decreased significantly after $14 \mathrm{D}$. The toxic effects of tetracyclines on plant growth have been 
demonstrated (Mathews and Reinhold 2013; Liu et al. 2020; Han et al. 2021; Li et al. 2021). In the experiment, the RGR of $M$. aquaticumw significantly increased with low concentration of CTC $(1 \mathrm{mg} / \mathrm{L})$ after $7 \mathrm{D}$. This phenomenon was often called hormesis, where low concentration of CTC may be used as a plant-specific nutrient source (Gomes et al. 2014; Liu et al. 2019). Low concentration of exogenous stress can stimulate the metabolic process of plants, which is also a self-protection mechanism of plants. Hormesis is usually the result of compensatory biological process after direct toxicity induction or initial interruption of homeostasis (Wang et al. 2016). It is worth noting that after 14 D of CTC, the toxic excitation effect disappeared. This may be due to the fact that after $14 \mathrm{D}$ of continuous exposure, $1 \mathrm{mg} / \mathrm{L}$ CTC has been higher than the concentration level that can promote the growth of M. aquaticum. After $7 \mathrm{D}$, CTC and OTC had almost no inhibition on the plant height and fresh weight of $M$. aquaticum. However, after $14 \mathrm{D}$, they not only significantly inhibited these two indexes, but also the inhibition degree under CTC treatments was higher than that of OTC. These results also indicated that CTC and OTC had a cumulative toxic effect on $M$. aquaticum, and CTC was more toxic to $M$. aquaticum than that of OTC over time. The difference in toxicity between CTC and OTC to non-targeted organisms may be species-specific. Under CTC and OTC combined treatments after $7 \mathrm{D}$, we found that the effect of $(50+50) \mathrm{mg} / \mathrm{L}$ on the RGR was significantly greater than that of $14 \mathrm{D}$. According to Abott model, the combined treatments of CTC and OTC at different concentrations had an additive or synergistic effect on the RGR of M. aquaticum, indicating that CTC and OTC may increase the toxic effects of both parties during short exposure time. Because both of them belong to tetracyclines, the same compound often has similar toxic sites and modes of action (Carusso et al. 2018). The potential additive and synergistic effects may be related to toxicity dynamics of antibiotics. During short-term exposure, the presence of one antibiotic isolates the metabolic enzymes that normally metabolize another antibiotic in the plant, allowing more of the antibiotic to reach its target site, and resulting in greater toxicity (Broderius et al. 2005; Yang et al. 2008). However, after $14 \mathrm{D}$, the addition of OTC made the mixture exhibit an antagonistic effect on the RGR of $M$. aquaticum under the treatment of $50 \mathrm{mg} / \mathrm{L} \mathrm{CTC}$, indicating that the presence of CTC and OTC will reduce the damage of both sides to the growth of $M$. aquaticum under long-term treatments. The possible reason is the competition of similar binding sites or the antagonism caused by mutual inhibition of toxicity in plant cells (Guo et al. 2015; Wang et al. 2018).

In plant cells, chloroplasts convert light energy into biological energy through high metabolic activity and electron transfer rate. Chlorophyll and carotenoid are pigments for photosynthesis in green plants and have been widely used as indicators of pollutant stress (Ma et al. 2016; Guo et al. 2020). After 14 D, the chlorophyll (chlorophyll a, chlorophyll $b$, and total chlorophyll contents) of $M$. aquaticum significantly decreased by either single or combined treatments. Likewise, the inhibitory effect of CTC on photosynthetic pigments was also stronger than that of OTC. The effects of tetracyclines on the contents of chlorophyll in plants have been reported in some literatures (Brain et al. 2005; Li et al. 2011; Rydzyński et al. 2017). During photosynthesis, plants need to absorb water for photodecomposition of water in chloroplasts. Therefore, CTC and OTC were likely to be absorbed into the plant along with water. The prokaryotic nature and bacterial structure of plant chloroplasts may make them potential target for tetracyclines (Wang et al. 2018). According to the Abott model, the interaction between CTC and OTC on 
the total chlorophyll content of $M$. aquaticum was additive or synergistic after $7 \mathrm{D}$, and antagonistic effect was only observed at $(10+50) \mathrm{mg} / \mathrm{L}$ of combined treatment. After $14 \mathrm{D}$, all the combined treatments showed antagonistic effect except for $(10+50) \mathrm{mg} / \mathrm{L}$ of CTC and OTC combined treatment. In addition, the interaction between CTC and OTC exposure on the total chlorophyll of M. aquaticum was more obvious than that on the RGR, but the change trend was generally consistent, that is, with the increase of exposure time, the interaction changed from additive or synergistic to antagonistic. The cumulative toxicity effects of CTC and OTC lead to the gradual occupation of binding sites in plants, and the two antibiotic molecules cannot effectively bind to the target to produce stronger toxicity (Yang et al. 2020). There was no significant change in the carotenoid content, except for a significant increase at $(50+50) \mathrm{mg} / \mathrm{L}$ after $14 \mathrm{D}$. The contents of carotenoid generally decreased in previous studies, which was inconsistent with our results (Di Marco et al. 2014; Li et al. 2021). It should be noted that Liu et al. (2020) found that there was no significant difference in the carotenoid content between Hydrocharis dubia (BI.) Backer and Trapa bispinosa Roxb, suggesting that the effects of tetracyclines on carotenoids in plants may be species-specific. In addition, studies have shown that carotenoids are effective quenchers of triple photosensitizer, singlet oxygen and peroxy free radicals (Chen et al. 2012). ROS can regulate the carotenoid concentration in plants by activating potential biosynthetic enzymes or genes encoding related enzymes (Zhong et al. 2018a). It is possible that the carotenoid can eliminate ROS produced by stress and maintain plant homeostasis through compensatory synthesis of carotenoids, which explained why the carotenoid content of M. aquaticum increased significantly at $(50+50) \mathrm{mg} / \mathrm{L}$.

There is a dynamic balance between the production and removal of ROS in plants under normal circumstances. $\mathrm{H}_{2} \mathrm{O}_{2}$ is a relatively stable ROS, which can usually measure the degree of plant stress $\mathrm{Wu}$ et al. 2010). There was no significant difference in the $\mathrm{H}_{2} \mathrm{O}_{2}$ content in each treatment group after $7 \mathrm{D}$. The phenomenon may be caused by delayed $\mathrm{H}_{2} \mathrm{O}_{2}$ of $M$. aquaticum response to CTC and OTC, or by the good operation of plant antioxidant system to remove excess $\mathrm{H}_{2} \mathrm{O}_{2}$. After $14 \mathrm{D}$, the $\mathrm{H}_{2} \mathrm{O}_{2}$ content of $M$. aquaticum increased with the mixture concentrations of CTC and OTC. The accumulation of $\mathrm{H}_{2} \mathrm{O}_{2}$ content indicated that the combined treatments of higher concentration of CTC and OTC could full cause the oxidative stress response of $M$. aquaticum. As a strong oxidant, $\mathrm{H}_{2} \mathrm{O}_{2}$ can cause oxidative damage to photosynthetic pigments, phospholipids, proteins and other biological macromolecules, thus aggravating membrane damage (Gunes et al. 2009). The decrease in photosynthetic pigments in the experiment was consistent with this explanation. The soluble protein content reflects the vitality of plant physiological activities and plays an important role in maintaining the stability of organisms. In the experiment, there was no significant difference in the content of soluble protein of $M$. aquaticum. This was different from the results of Li et al. (2021) and Zhou et al. (2020), but consistent with the results of Liu et al. (2020). The reason for no change in the soluble protein of M. aquaticum may be that: (1) CTC and OTC had no effect on the protein content of M. aquaticum. (2) The increase of ROS led to a compensatory increase in the protein content. Tukaj and Tukaj (2010) believed that the increase of ROS level might trigger signal transduction pathway, thus inducing a series of protein synthesis related to antioxidant response and protein repair in plants to maintain the stability of plants. 
Once the accumulation of ROS in plants is excessive, membrane lipid peroxidation will occur. MDA is the main product of membrane lipid peroxidation and usually used to measure the damage degree of plant cell membrane (Zhong et al. 2018b). After 7 D, the MDA content of M. aquaticum significantly decreased in $50 \mathrm{mg} / \mathrm{L} \mathrm{CTC}$ alone or combination, which was obviously unexpected. Most plants exposed to tetracyclines seem to be accompanied by oxidative damage, that is, a phase of increased MDA levels (Guo et al. 2020; Zhou et al. 2020). However, Li et al. (2021) found that the MDA content of $V$. natans also did not increase after $7 \mathrm{D}$ exposure to CTC. The decrease of membrane lipid peroxidation may be an adaptive response to stress (Nunes et al. 2015). After 14 D, there was no significant difference in the MDA content of $M$. aquaticum under single CTC/ OTC treatments, indicating that M. aquaticum did not suffer from membrane lipid peroxidation. Under the combined treatments of CTC and OTC, the MDA content increased first and then decreased. The maximum value of the MDA content appeared at $(1+50) \mathrm{mg} / \mathrm{L}$, indicating that the membrane damage was serious and caused oxidative stress in plants. The MDA content remained low in high concentration combined treatments of CTC and OTC $((10+50) \mathrm{mg} / \mathrm{L}$, $(50+50) \mathrm{mg} / \mathrm{L})$, which might indicate that the antioxidant system composed of various non-enzymes and antioxidant enzymes played an effective role in resisting oxidative stress and eliminating free radical damage in plants.

The antioxidant defense system of plants includes antioxidant enzymes and antioxidants, which can protect plants from oxidative damage (Liu et al. 2019). Antioxidant enzymes include SOD, CAT, and POD, etc. SOD is the first line of defense of plant's antioxidant system, which mainly converts superoxide anion radical $\left(\mathrm{O}^{2-}\right)$ into $\mathrm{H}_{2} \mathrm{O}_{2}$ and $\mathrm{O}_{2}$ (Wu et al. 2010). CAT and POD are two antioxidant enzymes that scavenge $\mathrm{H}_{2} \mathrm{O}_{2}$ (Zhong et al. 2018c). After $7 \mathrm{D}$ of CTC alone or combined treatments with OTC, the SOD, CAT, and POD activities of $M$. aquaticum showed a trend of increasing first and then decreasing at different concentrations. The increase of antioxidant enzymes indicated that ROS can be eliminated by activating the antioxidant enzyme system. The decrease of SOD activity may be due to the decrease of enzyme synthesis or the change of its subunit assembly leading to enzyme inactivation. The inactivation of SOD would aggravate the accumulation of ROS, but the results showed that the $\mathrm{H}_{2} \mathrm{O}_{2}$ content remained at the normal level, which might be due to the decomposition of ROS by CAT and POD. The decrease of CAT activity was much smaller than that of SOD and POD, and it remained at the control level under high concentration of CTC and high concentration of CTC and OTC combined treatments. The results indicated that after $7 \mathrm{D}$, the antioxidant system of $M$. aquaticum operated well, and CAT may be the main protective enzyme of $M$. aquaticum under single CTC and combined stress of CTC and OTC. After $7 \mathrm{D}$ of OTC, the activities of SOD and CAT as well as the contents of MDA and $\mathrm{H}_{2} \mathrm{O}_{2}$ did not change, the POD activity significantly decreased at $50 \mathrm{mg} / \mathrm{L}$ OTC. We speculated that the decrease of POD activity might be related to the potential enzyme toxicity of antibiotics. After $14 \mathrm{D}$ of combined treatments with CTC and OTC, the activities of three antioxidant enzymes showed different trends. The POD activity increased first and then returned to the control level, while the SOD activity decreased and the CAT activity remained unchanged. Our results were similar to those of Shang et al. (2015). After 14 D, the excessive ROS produced by $M$. aquaticum under combined stress of CTC and OTC may not be eliminated by CAT, but by POD, suggesting that POD may be the main protective enzyme under $14 \mathrm{D}$ of combined stress. The 
decrease of SOD activity was the oxidative damage induced by high combined concentration, and SOD, as the first line of defense of the antioxidant system, was destroyed. The inconsistency of enzyme activity indicated that the three enzymes were functionally independent. Peter et al. (1994) believed that $\mathrm{H}_{2} \mathrm{O}_{2}$ produced by SOD was not the only source of $\mathrm{H}_{2} \mathrm{O}_{2}$ consumed by CAT and POD. $\mathrm{H}_{2} \mathrm{O}_{2}$ can also be produced from activation of amino acid or cytochrome P450 oxidase. This may also be one of the reasons why the $\mathrm{H}_{2} \mathrm{O}_{2}$ content increased at high combined concentration of CTC and OTC. The sensitivity and action of antioxidant enzymes in $M$. aquaticum may vary according to the type of antibiotics and exposure time.

\section{Conclusion}

Based on the results of the present study, it can be concluded that: 1) After 14 D of CTC/ OTC, the inhibition degree on the plant height, RGR, and photosynthetic pigments of $M$. aquaticum was significantly strong than that after $7 \mathrm{D}$, showing obvious cumulative toxicity effect, and the toxicity of CTC was significantly stronger than that of OTC. 2) The combined effect of CTC and OTC were different at different concentration ratio and exposure time on $M$. aquaticum. After $7 \mathrm{D}$, the interaction between CTC and OTC on the RGR and total chlorophyll was mainly synergistic or additive. After $14 \mathrm{D}$, the interaction changed to antagonism or addition. The content of total chlorophyll was more sensitive to mixed stress than the RGR of M. aquaticum. 3) The combined presence of CTC and OTC can induce a certain degree of oxidative stress in leaf tissue, and stimulate the response of antioxidant system of $M$. aquaticum. The antioxidant defense system of $M$. aquaticum is not static, but varies with exposure time and stress intensity. After $7 \mathrm{D}$ of combined treatments, CAT was the main protective enzyme of $M$. aquaticum, while POD was the main protective enzyme after $14 \mathrm{D}$.

\section{Declarations}

\section{Ethical Approval}

This article does not contain any studies with human participants or animals performed by any of the authors.

\section{Consent to participate}

No applicable.

\section{Consent for publication}

Written informed consent for publication was obtained from all participants.

\section{Availability of date and materials}

All data generated or analysed during this study are included in this published article. 


\section{Competing interests}

The authors declare that the research was conducted in the absence of any commercial or financial relationships that could be construed as a potential conflict of interest.

\section{Funding}

the National Science Foundation of China (No. 31270410, No. 30970303)

the Scientific Research Project of Hubei Province Environmental Protection Department (2014HB07).

\section{Authors' contribution statements}

Jing Li: Conceptualization; Methodology; Resources; Investigation; Writing-Original Draft.

Zhonghua Wu: Supervision; Project administration; Funding acquisition.

\section{Acknowledgments}

This work was supported by the National Science Foundation of China (No. 31270410, No. 30970303) and the Scientific Research Project of Hubei Province Environmental Protection Department (2014HB07).

\section{References}

Ando T, Nagase H, Eguchi K, et al (2007) A NOVEL METHOD USING CYANOBACTERIA FOR ECOTOXICITY TEST OF VETERINARY ANTIMICROBIAL AGENTS. Environ Toxicol Chem 26:601. https://doi.org/10.1897/06-195R.1

Bradford M (1976) A rapid and sensitive method for the quantitation of microgram quantities of protein utilizing the principles of protein-dye binding. Anal Biochem 71:248-254

Brain RA, Wilson CJ, Johnson DJ, et al (2005) Effects of a mixture of tetracyclines to Lemna gibba and Myriophyllum sibiricum evaluated in aquatic microcosms. Environ Pollut 138:426-443. https://doi.org/10.1016/j.envpol.2005.04.021

Broderius SJ, Kahl MD, Elonen GE, et al (2005) A COMPARISON OF THE LETHAL AND SUBLETHAL TOXICITY OF ORGANIC CHEMICAL MIXTURES TO THE FATHEAD MINNOW (PIMEPHALES PROMELAS). Environ Toxicol Chem 24:3117. https://doi.org/10.1897/05-094R.1

Cang J, Zhao H (2013) Experimental Course of Plant Physiology. Higher Education press, Peking. pp. 151153 (in Chinese)

Carusso S, Juárez AB, Moretton J, Magdaleno A (2018) Effects of three veterinary antibiotics and their binary mixtures on two green alga species. Chemosphere 194:821-827. https://doi.org/10.1016/j.chemosphere.2017.12.047 
Chen L, Lang H, Liu F, et al (2018) Presence of Antibiotics in Shallow Groundwater in the Northern and Southwestern Regions of China. Groundwater 56:451-457. https://doi.org/10.1111/gwat.12596

Chen L, Zhou L, Liu Y, et al (2012) Toxicological effects of nanometer titanium dioxide (nano-TiO2) on Chlamydomonas reinhardtii. Ecotoxicol Environ Saf 84:155-162.

https://doi.org/10.1016/j.ecoenv.2012.07.019

Chesworth JC, Donkin ME, Brown MT (2004) The interactive effects of the antifouling herbicides Irgarol 1051 and Diuron on the seagrass Zostera marina (L.). Aquat Toxicol 66:293-305.

https://doi.org/10.1016/j.aquatox.2003.10.002

Daghrir R, Drogui P (2013) Tetracycline antibiotics in the environment: A review. Environ Chem Lett 11:209-227. https://doi.org/10.1007/s10311-013-0404-8

Di Marco G, Gismondi A, Canuti L, et al (2014) Tetracycline accumulates in Iberis sempervirens L. through apoplastic transport inducing oxidative stress and growth inhibition. Plant Biol 16:792-800.

https://doi.org/10.1111/plb.12102

Gatidou G, Thomaidis NS (2007) Evaluation of single and joint toxic effects of two antifouling biocides, their main metabolites and copper using phytoplankton bioassays. Aquat Toxicol 85:184-191. https://doi.org/10.1016/j.aquatox.2007.09.002

Gomes MP, Smedbol E, Chalifour A, et al (2014) Alteration of plant physiology by glyphosate and its byproduct aminomethylphosphonic acid: An overview. J Exp Bot 65:4691-4703.

https://doi.org/10.1093/jxb/eru269

Gunes A, Pilbeam DJ, Inal A (2009) Effect of arsenic-phosphorus interaction on arsenic-induced oxidative stress in chickpea plants. Plant Soil 314:211-220. https://doi.org/10.1007/s11104-008-9719-9

Guo R, Xie W, Chen J (2015) Assessing the combined effects from two kinds of cephalosporins on green alga (Chlorella pyrenoidosa) based on response surface methodology. Food Chem Toxicol 78:116-121. https://doi.org/10.1016/j.fct.2015.02.007

Guo X, Liu M, Zhong H, et al (2020) Responses of the growth and physiological characteristics of Myriophyllum aquaticum to coexisting tetracyclines and copper in constructed wetland microcosms. Environ Pollut 261:114204. https://doi.org/10.1016/j.envpol.2020.114204

Guo X, Wang P, Li Y, et al (2019) Effect of copper on the removal of tetracycline from water by Myriophyllum aquaticum: Performance and mechanisms. Bioresour Technol 291:121916. https://doi.org/10.1016/j.biortech.2019.121916

Han T, Wang B, Wu Z, et al (2021) Providing a view for toxicity mechanism of tetracycline by analysis of the connections between metabolites and biologic endpoints of wheat. Ecotoxicol Environ Saf 212:111998. https://doi.org/10.1016/j.ecoenv.2021.111998 
Hou J, Wang C, Mao D, Luo Y (2016) The occurrence and fate of tetracyclines in two pharmaceutical wastewater treatment plants of Northern China. Environ Sci Pollut Res 23:1722-1731. https://doi.org/10.1007/s11356-015-5431-5

Jampeetong A, Brix $\mathrm{H}$ (2009) Effects of $\mathrm{NaCl}$ salinity on growth, morphology, photosynthesis and proline accumulation of Salvinia natans. Aquat Bot 91:181-186. https://doi.org/10.1016/j.aquabot.2009.05.003

Jiang Y, Li M, Guo C, et al (2014) Distribution and ecological risk of antibiotics in a typical effluentreceiving river (Wangyang River) in north China. Chemosphere 112:267-274.

https://doi.org/10.1016/j.chemosphere.2014.04.075

Jijie R, Mihalache G, Balmus I-M, et al (2021) Zebrafish as a Screening Model to Study the Single and Joint Effects of Antibiotics. Pharmaceuticals 14:578. https://doi.org/10.3390/ph14060578

Klein EY, Van Boeckel TP, Martinez EM, et al (2018) Global increase and geographic convergence in antibiotic consumption between 2000 and 2015. Proc Natl Acad Sci U S A 115:E3463-E3470. https://doi.org/10.1073/pnas.1717295115

Kovalakova P, Cizmas L, McDonald TJ, et al (2020) Occurrence and toxicity of antibiotics in the aquatic environment: A review. Chemosphere 251:126351. https://doi.org/10.1016/j.chemosphere.2020.126351

Li J, Yang L, Wu Z (2021) Toxicity of chlortetracycline and oxytetracycline on Vallisneria natans (Lour.) Hare. Environ Sci Pollut Res 27:1-8. https://doi.org/10.1007/s11356-021-14922-2

Li Z, Xie X, Zhang S, Liang Y (2011) Negative Effects of Oxytetracycline on Wheat (Triticum aestivum L.) Growth, Root Activity, Photosynthesis, and Chlorophyll Contents. Agric Sci China 10:1545-1553. https://doi.org/10.1016/S1671-2927(11)60150-8

Lichtenthaler Hartmut K., Wellburn AR (1983) Determinations of total carotenoids and chlorophylls a and b of leaf extracts in different solvents. Biochem Soc Trans 11:591-592. https://doi.org/10.1042/bst0110591

Liu F, Zhang S, Luo P, et al (2018) Purification and reuse of non-point source wastewater via Myriophyllum-based integrative biotechnology: A review. Bioresour Technol 248:3-11. https://doi.org/10.1016/j.biortech.2017.07.181

Liu F, Zhang S, Wang Y, et al (2016) Nitrogen removal and mass balance in newly-formed Myriophyllum aquaticum mesocosm during a single 28-day incubation with swine wastewater treatment. J Environ Manage 166:596-604. https://doi.org/10.1016/j.jenvman.2015.11.020

Liu N, Zhong G, Zhou J, et al (2019) Separate and combined effects of glyphosate and copper on growth and antioxidative enzymes in Salvinia natans (L.) All. Sci Total Environ 655:1448-1456.

https://doi.org/10.1016/j.scitotenv.2018.11.213 
Liu P, Li M (2007) Experimental Techniques of Plant Physiology. Science Press, Peking. pp. 123-125 (in Chinese)

Liu Y, Pang Y, Yang L, et al (2020) Responses of Hydrocharis dubia (BI.) Backer and Trapa bispinosa roxb. to tetracycline exposure. Ecotoxicol Environ Saf 202:110890.

https://doi.org/10.1016/j.ecoenv.2020.110890

Lu J, Zhang Y, Wu J, et al (2019) Occurrence and spatial distribution of antibiotic resistance genes in the Bohai Sea and Yellow Sea areas, China. Environ Pollut 252:450-460.

https://doi.org/10.1016/j.envpol.2019.05.143

Ma Y, Rajkumar M, Zhang C, Freitas H (2016) Inoculation of Brassica oxyrrhina with plant growth promoting bacteria for the improvement of heavy metal phytoremediation under drought conditions. $\mathrm{J}$ Hazard Mater 320:36-44. https://doi.org/10.1016/j.jhazmat.2016.08.009

Mathews S, Reinhold D (2013) Biosolid-borne tetracyclines and sulfonamides in plants. Environ Sci Pollut Res 20:4327-4338. https://doi.org/10.1007/s11356-013-1693-y

Miazek K, Brozek-Pluska B (2019) Effect of phrs and pcps on microalgal growth, metabolism and microalgae-based bioremediation processes: A review. Int J Mol Sci 20:

https://doi.org/10.3390/ijms20102492

Nieder R, Benbi DK, Reichl FX (2018) Soil as a Transmitter of Human Pathogens. In: Soil Components and Human Health. Springer Netherlands, Dordrecht, pp 723-827

Nunes B, Antunes SC, Gomes R, et al (2015) Acute Effects of Tetracycline Exposure in the Freshwater Fish Gambusia holbrooki: Antioxidant Effects, Neurotoxicity and Histological Alterations. Arch Environ Contam Toxicol 68:371-381. https://doi.org/10.1007/s00244-014-0101-z

Pan M, Chu LM (2018) Occurrence of antibiotics and antibiotic resistance genes in soils from wastewater irrigation areas in the Pearl River Delta region, southern China. Sci Total Environ 624:145-152. https://doi.org/10.1016/j.scitotenv.2017.12.008

Peters LD, Porte C, Albaigés J, Livingstone DR (1994) 7-ethoxyresorufin 0-deethylase (EROD) and antioxidant enzyme activities in larvae of sardine (Sardina pilchardus) from the north coast of Spain. Mar Pollut Bull 28:299-304. https://doi.org/10.1016/0025-326X(94)90154-6

Qiu W, Liu X, Yang F, et al (2020) Single and joint toxic effects of four antibiotics on some metabolic pathways of zebrafish (Danio rerio) larvae. Sci Total Environ 716:137062.

https://doi.org/10.1016/j.scitotenv.2020.137062

Qiu W, Sun J, Fang M, et al (2019) Occurrence of antibiotics in the main rivers of Shenzhen, China: Association with antibiotic resistance genes and microbial community. Sci Total Environ 653:334-341. https://doi.org/10.1016/j.scitotenv.2018.10.398 
Rydzyński D, Piotrowicz-Cieślak Al, Grajek H, Michalczyk DJ (2017) Instability of chlorophyll in yellow lupin seedlings grown in soil contaminated with ciprofloxacin and tetracycline. Chemosphere 184:62-73. https://doi.org/10.1016/j.chemosphere.2017.05.147

Scaria J, Anupama KV, Nidheesh PV (2021) Tetracyclines in the environment: An overview on the occurrence, fate, toxicity, detection, removal methods, and sludge management. Sci Total Environ 771:145291. https://doi.org/10.1016/j.scitotenv.2021.145291

Shang AH, Ye J, Chen DH, et al (2015) Physiological effects of tetracycline antibiotic pollutants on nontarget aquatic Microcystis aeruginosa. J Environ Sci Heal - Part B Pestic Food Contam Agric Wastes 50:809-818. https://doi.org/10.1080/03601234.2015.1058100

Shi H (2016) Experimental Guidance of Plant Stress Physiology. Science Press, Peking. pp. 58-75 (in Chinese)

Siedlewicz G, Żak A, Sharma L, et al (2020) Effects of oxytetracycline on growth and chlorophyll a fluorescence in green algae (Chlorella vulgaris), diatom (Phaeodactylum tricornutum) and cyanobacteria (Microcystis aeruginosa and Nodularia spumigena). Oceanologia 62:214-225.

https://doi.org/10.1016/j.oceano.2019.12.002

Suzuki S, Nakanishi S, Tamminen M, et al (2019) Occurrence of sul and tet(M) genes in bacterial community in Japanese marine aquaculture environment throughout the year: Profile comparison with Taiwanese and Finnish aquaculture waters. Sci Total Environ 669:649-656.

https://doi.org/10.1016/j.scitotenv.2019.03.111

Tasho RP, Cho JY (2016) Veterinary antibiotics in animal waste, its distribution in soil and uptake by plants: A review. Sci Total Environ 563-564:366-376. https://doi.org/10.1016/j.scitotenv.2016.04.140

Tukaj S, Tukaj Z (2010) Distinct chemical contaminants induce the synthesis of Hsp70 proteins in green microalgae Desmodesmus subspicatus: Heat pretreatment increases cadmium resistance. J Therm Biol 35:239-244. https://doi.org/10.1016/j.jtherbio.2010.05.007

Walters E, McClellan K, Halden RU (2010) Occurrence and loss over three years of 72 pharmaceuticals and personal care products from biosolids-soil mixtures in outdoor mesocosms. Water Res 44:60116020. https://doi.org/10.1016/j.watres.2010.07.051

Wang T, Wang D, Lin Z, et al (2016) Prediction of mixture toxicity from the hormesis of a single chemical: A case study of combinations of antibiotics and quorum-sensing inhibitors with gram-negative bacteria. Chemosphere 150:159-167. https://doi.org/10.1016/j.chemosphere.2016.02.018

Wang Z, Chen Q, Hu L, Wang M (2018) Combined effects of binary antibiotic mixture on growth, microcystin production, and extracellular release of Microcystis aeruginosa: application of response surface methodology. Environ Sci Pollut Res 25:736-748. https://doi.org/10.1007/s11356-017-0475-3 
Wei R, Ge F, Huang S, et al (2011) Occurrence of veterinary antibiotics in animal wastewater and surface water around farms in Jiangsu Province, China. Chemosphere 82:1408-1414.

https://doi.org/10.1016/j.chemosphere.2010.11.067

Wei S, Wang F, Chen Y, et al (2018) The joint toxicity effect of five antibiotics and dibutyl phthalate to luminescent bacteria (Vibrio fischeri). Environ Sci Pollut Res 25:26504-26511.

https://doi.org/10.1007/s11356-018-2720-9

Wu Z, Yu D, Li J, et al (2010) Growth and antioxidant response in Hydrocharis dubis (BI.) Backer exposed to linear alkylbenzene sulfonate. Ecotoxicology 19:761-769. https://doi.org/10.1007/s10646-009-0453-8

Yang LH, Ying GG, Su HC, et al (2008) Growth-inhibiting effects of 12 antibacterial agents and their mixtures on the freshwater microalga Pseudokirchneriella subcapitata. Environ Toxicol Chem 27:12011208. https://doi.org/10.1897/07-471.1

Yang R, Xia X, Wang J, et al (2020) Dose and time-dependent response of single and combined artificial contamination of sulfamethazine and copper on soil enzymatic activities. Chemosphere 250 :.

https://doi.org/10.1016/j.chemosphere.2020.126161

Zhi S, Zhou J, Yang F, et al (2018) Systematic analysis of occurrence and variation tendency about 58 typical veterinary antibiotics during animal wastewater disposal processes in Tianjin, China. Ecotoxicol Environ Saf 165:376-385. https://doi.org/10.1016/j.ecoenv.2018.08.101

Zhong G, Wu Z, Liu N, Yin J (2018a) Phosphate alleviation of glyphosate-induced toxicity in Hydrocharis dubia (BI.) Backer. Aquat Toxicol 201:91-98. https://doi.org/10.1016/j.aquatox.2018.05.025

Zhong G, Wu Z, Yin J, Chai L (2018b) Responses of Hydrilla verticillata (L.f.) Royle and Vallisneria natans (Lour.) Hara to glyphosate exposure. Chemosphere 193:385-393.

https://doi.org/10.1016/j.chemosphere.2017.10.173

Zhong G, Wu Z, Yin J, Chai L (2018c) Responses of Hydrilla verticillata (L.f.) Royle and Vallisneria natans (Lour.) Hara to glyphosate exposure. Chemosphere 193:385-393.

https://doi.org/10.1016/j.chemosphere.2017.10.173

Zhou X, Jiang X, Gao S, et al (2020) Effects of oxytetracycline dihydrate and sulfamethoxazole on Microcystis aeruginosa and Chlamydomonas microsphaera. J Oceanol Limnol.

https://doi.org/10.1007/s00343-020-9214-6

\section{Figures}



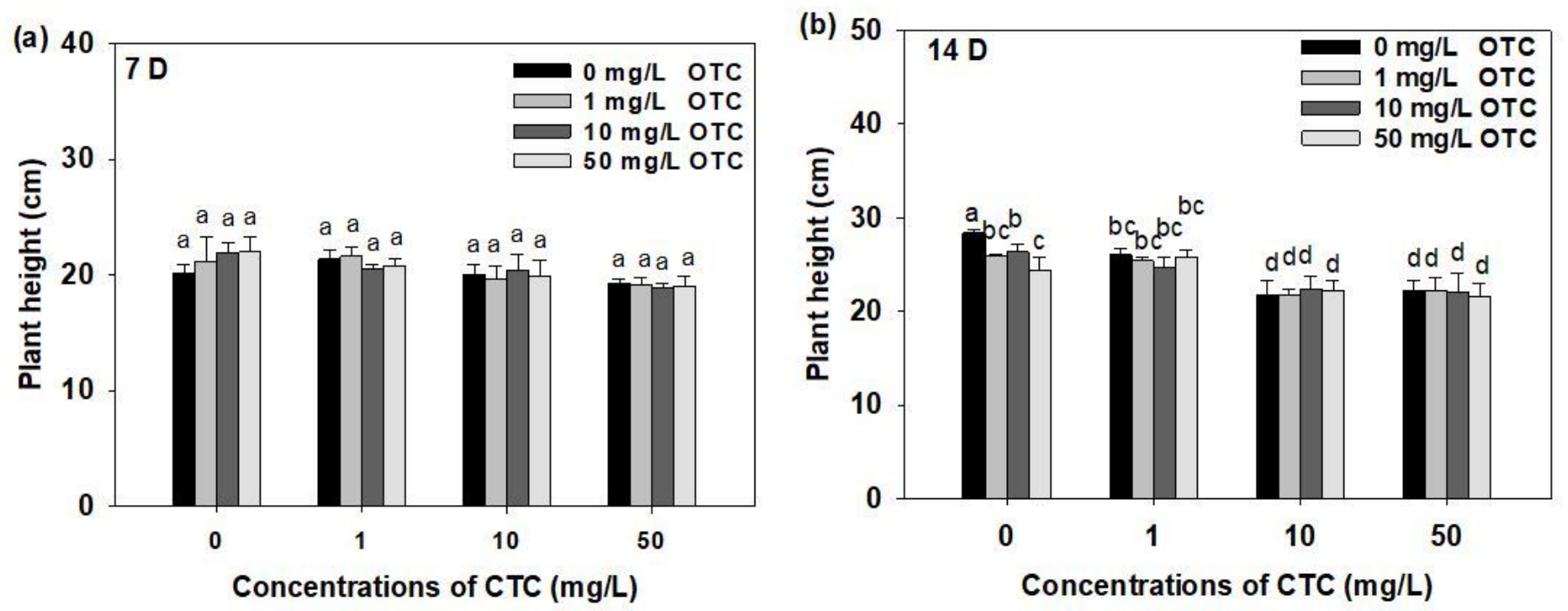

Figure 1

Effects of CTC, OTC, and their mixture on plant height of M. aquaticum after $7 \mathrm{D}(\mathrm{a})$ and $14 \mathrm{D}$ (b). All values are the mean of three replicates \pm standard deviation. Bars with different letters are significantly different between treatments ( $p \leq 0.05$, Duncan test).
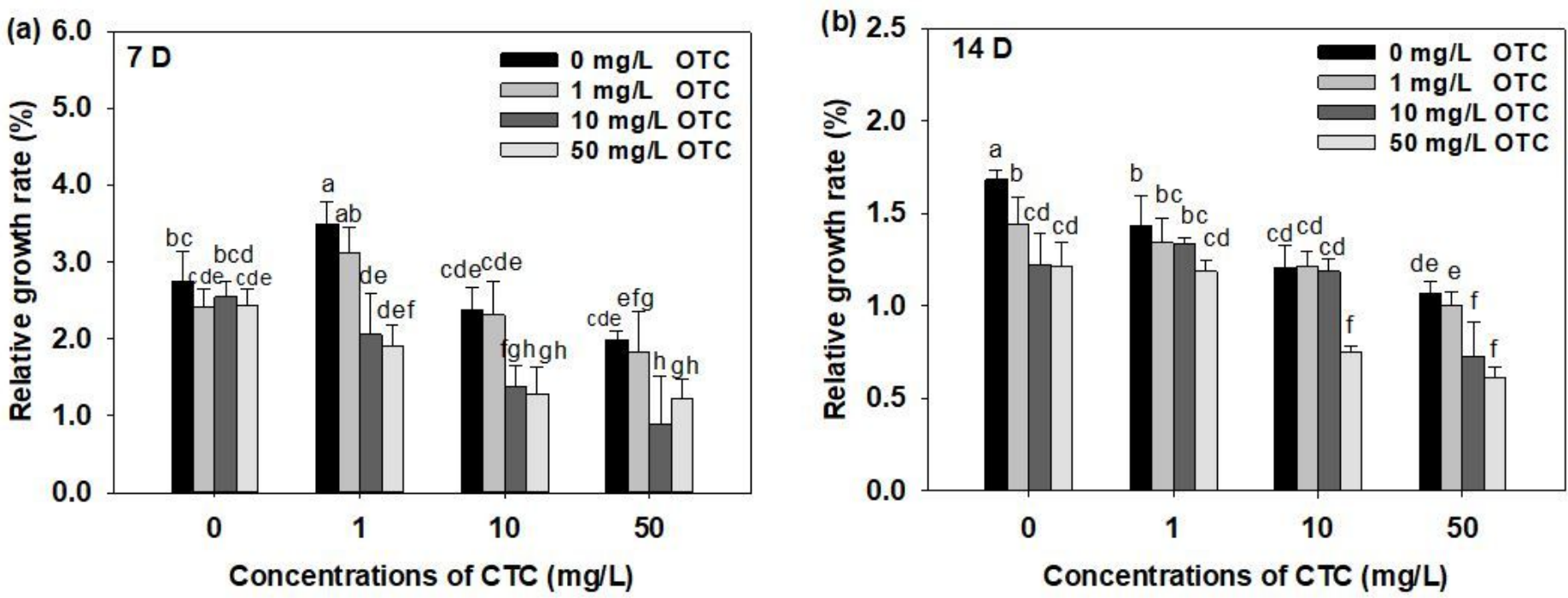

Figure 2

Effects of CTC, OTC, and their mixture on relative growth rate of $M$. aquaticum after $7 \mathrm{D}$ (a) and $14 \mathrm{D}(\mathrm{b})$. All values are the mean of three replicates \pm standard deviation. Bars with different letters are significantly different between treatments ( $p \leq 0.05$, Duncan test). 

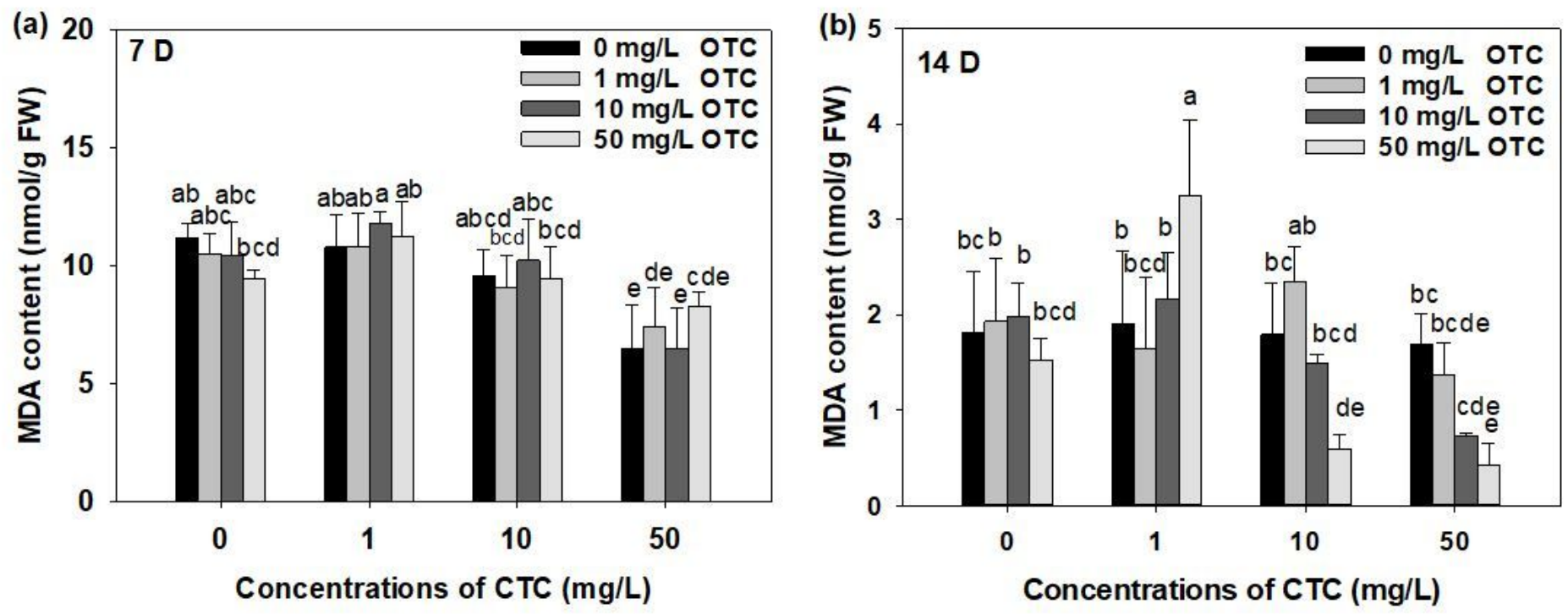

Figure 3

Effects of CTC, OTC, and their mixture on MDA content of M. aquaticum after 7 D (a) and 14 D (b). All values are the mean of three replicates \pm standard deviation. Bars with different letters are significantly different between treatments ( $p \leq 0.05$, Duncan test).
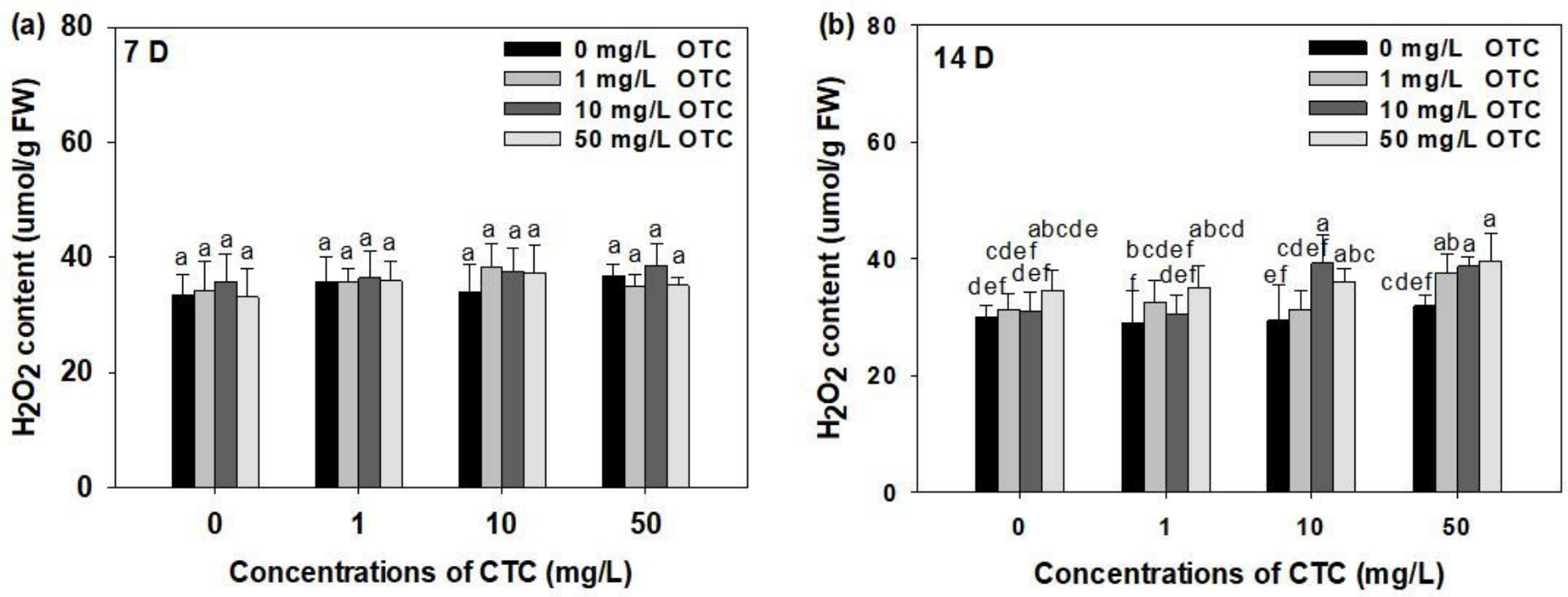

Figure 4

Effects of CTC, OTC, and their mixture on $\mathrm{H} 2 \mathrm{O} 2$ content of M. aquaticum after $7 \mathrm{D}(\mathrm{a})$ and $14 \mathrm{D}(\mathrm{b})$. All values are the mean of three replicates \pm standard deviation. Bars with different letters are significantly different between treatments ( $p \leq 0.05$, Duncan test). 

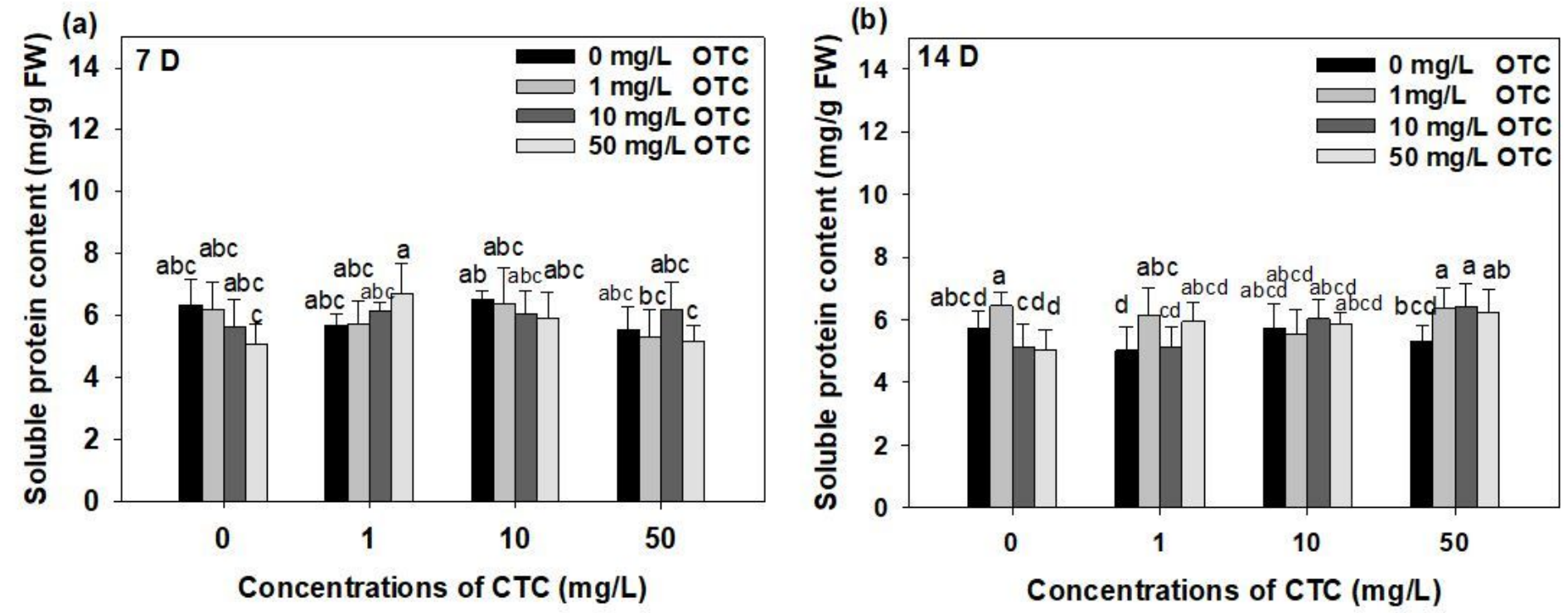

Figure 5

Effects of CTC, OTC, and their mixture on soluble protein content of M. aquaticum after 7 D (a) and 14 D (b). All values are the mean of three replicates \pm standard deviation. Bars with different letters are significantly different between treatments ( $p \leq 0.05$, Duncan test). 

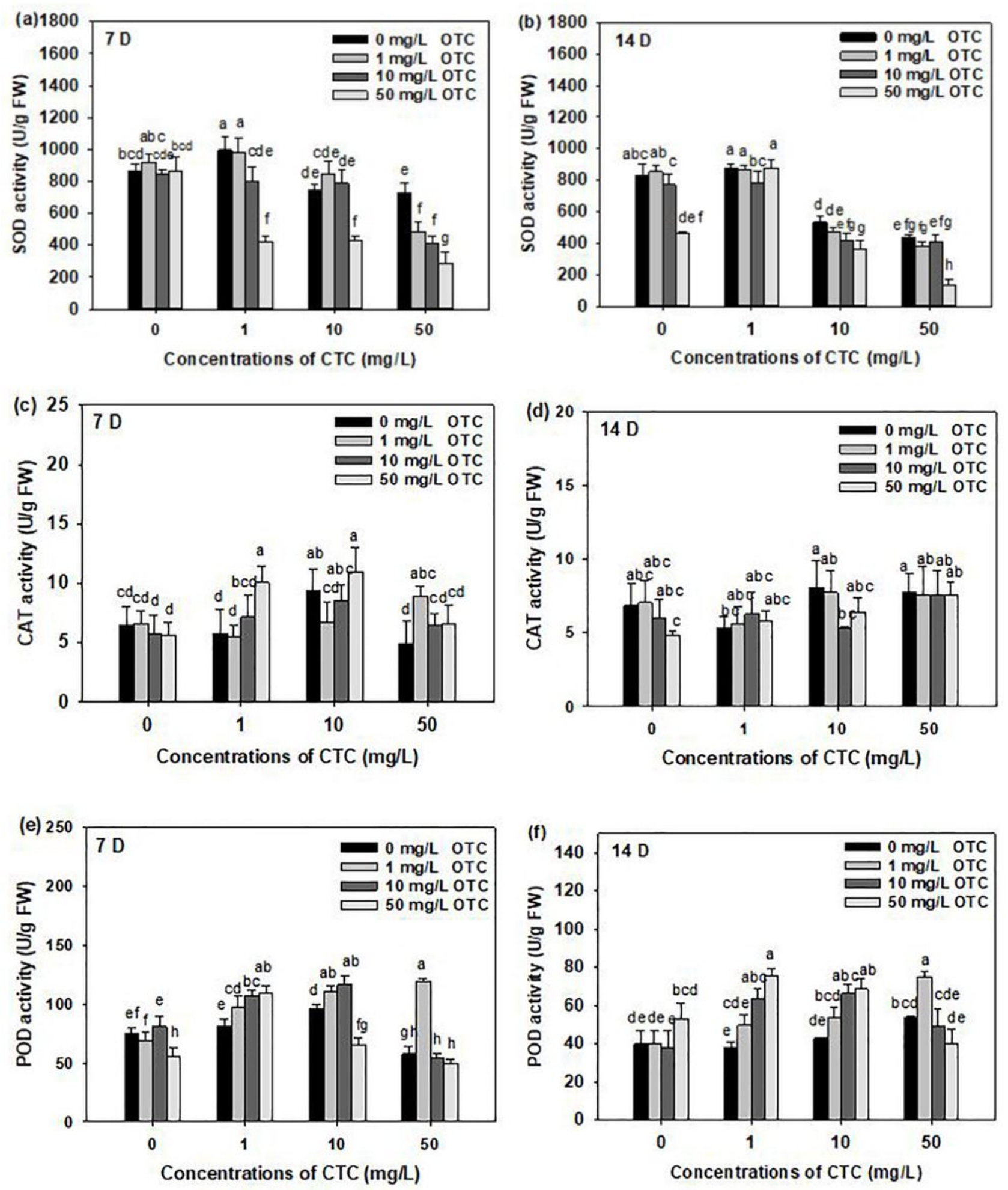

Figure 6

Effects of CTC, OTC, and their mixture on SOD (a), CAT (c), and POD (e) activities of M. aquaticum after 7 D. Effects of CTC, OTC, and their mixture on SOD (b), CAT (d), and POD (f) activities of M. aquaticum after $14 \mathrm{D}$. All values are the mean of three replicates \pm standard deviation. Bars with different letters are significantly different between treatments ( $p \leq 0.05$, Duncan test). 